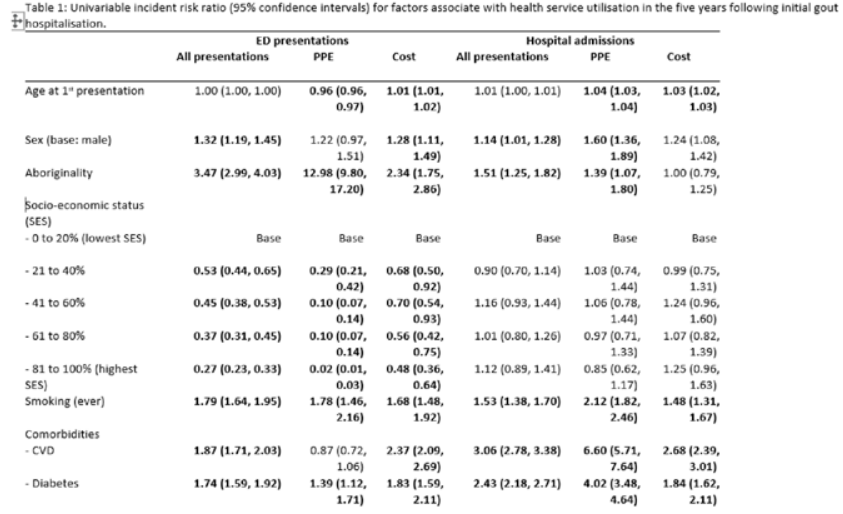

Acknowledgements: The authors wish to thank the staff at the Western Australian Data Linkage Branch and the Hospital Morbidity Data Collection, and the Death Registrations and the Emergency Department Data Collection.

Disclosure of Interests: None declared.

DOI: 10.1136/annrheumdis-2021-eular.4166

\section{POS1148 RISK FACTORS FOR POLYARTICULAR GOUT FLARES-ANALYSIS OF A LONGITUDINAL ONLINE GOUT FOLLOW-UP STUDY}

J. Dau ${ }^{1}$, N. Mccormick' ${ }^{1}$ S. Stratton ${ }^{1}$, C. Yokose ${ }^{1}$, C. Chen ${ }^{2}$, T. Neogi ${ }^{3}$, D. Hunter ${ }^{4}$, K. Saag ${ }^{5}$, Y. Zhang ${ }^{1}$, H. Choi ${ }^{1} .{ }^{1}$ Massachusetts General Hospital, Division of Rheumatology, Allergy, and Immunology, Boston, United States of America; ${ }^{2}$ Boston University School of Public Health, Biostatistics \& Epidemiology Data Analytics Center, Boston, United States of America; ${ }^{3}$ Boston University School of Medicine, Section of Rheumatology, Boston, United States of America; ${ }^{4}$ University of Sydney, Institute of Bone and Joint Research, Sydney, Australia; ${ }^{5}$ University of Alabama Birmingham, Division of Clinical Immunology and Rheumatology, Birmingham, United States of America

Background: There are known and established risk factors for gout flares; however, no study has examined the factors specifically associated with a polyarticular gout flare.

Objectives: Evaluate risk factors of a polyarticular gout flare in a longitudinal study of individuals with gout.

Methods: We used data from the Boston Online Gout Study, a longitudinal internet-based case-crossover study, where gout patients with at least one flare within the past year were enrolled across the US. Participants $(\mathrm{N}=903)$ were followed prospectively for 1 year via the internet to collect information on gout flares and related data including number and specific joints involved, medical comorbidities, diet, exercise and medications.

A polyarticular gout flare was defined as having 3 or more joints involved during a patient-reported flare period. Individuals with at least one flare (to determine flare pattern) during follow-up were included in the analysis. Univariable associations were first assessed to determine factors were associated with polyarticular joint flares. was used to adjust for confounders. When assessing the association of each risk factor with prevalent polyarticular joint involvement, we used multivariable logistic regression, adjusting specific confounders guided by causal diagram. Results: There were 724 participants with at least one flare with a mean and median age of 55 years. The cohort was $78 \%$ male and $89 \%$ White with a mean gout disease duration of 8.1 years (median 5). 197 (27\%) had a polyarticular gout flare. In univariable analysis (Table 1), female sex, osteoarthritis, obesity, heart failure, hypertension, chronic kidney disease and gout related medication use were each associated with higher odds of polyarticular gout flare, whereas higher education, alcohol use at study enrollment and aspirin use were associated with lower odds. In multivariable analysis, obesity, osteoarthritis and heart failure remained associated with a higher odds of polyarticular gout flare, whereas education remained inversely associated.

Conclusion: In this prospective cohort of gout patients, obesity, heart failure and osteoarthritis were independently associated with higher odds for polyarticular gout flares. Female sex was also positively associated, whereas higher education was protective. The positive association with gout-related medications likely reflects residual confounding by indication. If confirmed, these findings would help identify those at risk for polyarticular flares to help improve clinical care.
Table 1. Associations with Polyarticular Gout Flare ( $\geq 3$ joints)

\begin{tabular}{|c|c|c|c|c|}
\hline Risk Factor & & $\begin{array}{l}\text { Univariable OR } \\
\qquad(95 \% \mathrm{Cl})\end{array}$ & $\begin{array}{l}\text { Age- and Sex- } \\
\text { Adjusted OR } \\
\quad(95 \% \mathrm{Cl})\end{array}$ & $\begin{array}{l}\text { Multivariable } \\
\text { OR }^{\star}(95 \% \mathrm{Cl})\end{array}$ \\
\hline $\begin{array}{l}\text { Age } \geq 55 \text { years }(v s \\
\quad<55)\end{array}$ & & $0.82(0.59,1.14)$ & $0.77(0.56,1.08)$ & $0.70(0.49,1.01)$ \\
\hline Female Sex & & $1.51(1.04,2.22)$ & $1.55(1.03,2.32)$ & $1.21(0.78,1.88)$ \\
\hline $\begin{array}{l}\text { White Race (vs } \\
\text { Non-White) }\end{array}$ & & $0.89(0.54,1.48)$ & $0.93(0.56,1.54)$ & $0.75(0.44,1.28)$ \\
\hline $\begin{array}{l}\text { Education (vs High } \\
\text { School or Less) }\end{array}$ & $\begin{array}{l}\text { Some college } \\
\text { College } \\
\text { Post-graduate }\end{array}$ & $\begin{array}{c}0.63(0.37,1.07) \\
0.45(0.25,0.78) \\
0.42(0.25,0.72)\end{array}$ & $\begin{array}{l}0.53(0.37,1.07) \\
0.46(0.26,0.81) \\
0.44(0.26,0.76)\end{array}$ & $\begin{array}{l}0.68(0.39,1.17) \\
0.49(0.27,0.88) \\
0.48(0.28,0.84)\end{array}$ \\
\hline $\begin{array}{l}\text { Body Mass Index }(\mathrm{kg} / \\
\left.\mathrm{m}^{2}\right) \text { at Enrollment } \\
(\mathrm{vs}<25)\end{array}$ & $\begin{array}{c}25-29.9 \\
\geq 30\end{array}$ & $\begin{array}{l}1.69(0.85,3.33) \\
2.38(1.24,4.58)\end{array}$ & $\begin{array}{l}1.77(0.89,3.51) \\
2.30(1.19,4.43)\end{array}$ & $\begin{array}{l}1.82(0.90,3.65) \\
2.19(1.12,4.28)\end{array}$ \\
\hline $\begin{array}{l}\text { Alcohol Use at } \\
\text { Enrollment (vs. } \\
\text { Non-Use) }\end{array}$ & & $0.60(0.40,0.89)$ & $0.60(0.40,0.91)$ & $\star \star$ \\
\hline $\begin{array}{c}\text { Gout Duration } \geq 5 \\
\text { years }(v s<5)\end{array}$ & & $0.85(0.61,1.18)$ & $0.93(0.66,1.31)$ & $0.95(0.66,1.35)$ \\
\hline $\begin{array}{l}\text { Presence of } \\
\text { Comorbidities at } \\
\text { Enrollment (vs } \\
\text { Absence) }\end{array}$ & $\begin{array}{l}\text { Osteoarthritis } \\
\text { Heart Failure } \\
\text { Hypertension } \\
\text { Chronic Kidney } \\
\text { Disease }\end{array}$ & $\begin{array}{l}2.35(1.45,3.81) \\
2.06(1.11,3.81) \\
1.61(1.08,2.40) \\
1.97(1.03,3.78)\end{array}$ & $\begin{array}{l}2.37(1.43,3.95) \\
2.21(1.17,4.17) \\
1.69(1.10,2.60) \\
2.11(1.09,4.11)\end{array}$ & $\begin{array}{c}2.39(1.42,4.04) \\
2.03(1.06,3.91) \\
\star \star \\
\star \star\end{array}$ \\
\hline $\begin{array}{l}\text { Medication Use at } \\
\text { Enrollment } \\
\text { (vs No Use) }\end{array}$ & $\begin{array}{l}\text { Allopurinol } \\
\text { Diuretics } \\
\text { Oral Steroids } \\
\text { Aspirin }\end{array}$ & $\begin{array}{l}1.58(1.13,2.22) \\
1.53(1.06,2.21) \\
2.21(1.16,4.18) \\
0.68(0.47,0.98)\end{array}$ & $\begin{array}{l}1.59(1.13,2.23) \\
1.59(1.06,2.38) \\
2.26(1.19,4.31) \\
0.72(0.49,1.07)\end{array}$ & $\begin{array}{l}* \star \\
\star * \\
* \star \\
\star *\end{array}$ \\
\hline
\end{tabular}

${ }^{*}$ Mutually adjusted for the variables in this column ${ }^{\star \star}$ Not included in model

Acknowledgements: NIH P50AR060772.

Disclosure of Interests: Jonathan Dau: None declared, Natalie McCormick: None declared, Sarah Stratton: None declared, Chio Yokose: None declared Clara Chen: None declared, Tuhina Neogi Shareholder of: Lilly, EMD Merck Serono, Novartis, Regeneron, Pfizer/Lilly, David Hunter Shareholder of: Pfizer, Lilly, Merck Serono, Kenneth Saag Consultant of: Arthrosi, Horizon Therapeutics plc, Atom Bioscience, LG Pharma, Takeda, Mallinkrodt, SOBI, Grant/research support from: Horizon Therapeutics plc, Shanton, SOBI, Yuqing Zhang: None declared, Hyon Choi Consultant of: Ironwood, Selecta, Horizon, Takeda, Kowa, Vaxart, Grant/research support from: Ironwood, Horizon.

DOI: 10.1136/annrheumdis-2021-eular.4168

\section{POS1149 CARDIOVASCULAR RISK STATUS AND OBESITY IN GOUT COMPARED TO HEALTHY MEXICAN SUBJECTS: A CASE-CONTROLS STUDY WITH A PROPENSITY SCORE-MATCHED ANALYSIS}

R. Jimenez-Soto ${ }^{1}$, A. Sanchez Rodríguez ${ }^{2}$, C. Moreno del Castillo ${ }^{1}$, A. Turrent ${ }^{2}$, P. E. Bermudez Bermejo ${ }^{2}$, R. Burgos-Vargas ${ }^{3}$, C. Gómez-Ruiz ${ }^{3}$, J. Vazquez Mellado ${ }^{3} .{ }^{1} A B C$ Medical Center, Internal Medicine, Mexico City, Mexico; ${ }^{2} A B C$ Medical Center, Rheumatology, Mexico City, Mexico; ${ }^{3}$ Hospital General de Mexico, Rheumatology, Mexico City, Mexico

Background: Atherosclerotic cardiovascular diseases (ASCVD), metabolic syndrome and hyperuricemia due to an increment in their incidence world-wide, but information regarding the 10-year estimated risk in gout vs. healthy subjects is scarce.

Objectives: To assess baseline the 10-year cardiovascular risk and high-risk status in gout patients compared to healthy controls.

Methods: Data from 494 gout paired to controls in a ratio of 1:1 matched with age, sex and body mass index (BMI) and stratified by normal $\left(\leq 24.9 \mathrm{Kg} / \mathrm{m}^{2}\right)$, overweight $\left(25-29.9 \mathrm{Kg} / \mathrm{m}^{2}\right)$ and obese $\left(\geq 30 \mathrm{Kg} / \mathrm{m}^{2}\right)$. Controls were asymptomatic subjects attending a preventive clinic in Mexico City. We used the Framing ham Risk Score for Coronary Heart Disease (FRS-CHD) and the 2013 American College of Cardiology/American Heart Association (2013 ACC/AHA). Additionally, high risk status was defined according to pre-defined cutoff points for FRSCHD ( $\geq 20 \%)$ and ACC/AHA $2013(\geq 7.5 \%)$.

Results: Data from 494 gout and 494 controls. Gout patients were male 97.4\%, $47(\mathrm{SD} \pm 13)$ years, mean BMI of $28.4(\mathrm{SD} \pm 4.31) \mathrm{Kg} / \mathrm{m}^{2}$. Age, sex, and BMI and subgroups were equilibrated $(\mathrm{p}=\mathrm{NS})$. Gout patients had higher 10 -year estimated risk vs. controls nevertheless, only FRS-CHD reached statistically significant difference with 9.38 vs. $7.5 \pm 5.74$ ( $p<0.001)$; For 2013 ACC/AHA $4.94 \pm 6.16$ vs $5.23 \pm 6.78,(p=0.49)$. Further stratification by BMI groups revealed that subjects 
with gout in normal and overweight categories were had higher risk vs. controls with FRS-CHD score of $8.86 \pm 8.05$ vs. $6.53 \pm 6.41(p=0.03)$ and $9.37 \pm 7.72$ vs. $7.89 \pm 5.58(p=0.01)$, respectively. No differences for 2013 ACC/AHA in global and BMI-stratified comparisons. Proportion of high-risk subjects were similar in both groups regardless of BMI category: for FRS-CHD 7.5 vs $4.7 \%(p=0.06)$ and 2013 ACC/AHA with 21.5 vs. $17.8 \%(p=0.14)$.

Conclusion: Normal BMI or overweight Mexican patients with gout may be at higher 10-year estimated cardiovascular risk compared to matched age, gender and BMI healthy controls. Obese gout subjects are at high risk with non-statistical significance scores for FRS-CHD or 2013 ACC/AHA compared to controls. REFERENCES:

[1] Acosta-Cázares B, Escobedo-de la Peña J. High burden of cardiovascular disease risk factors in Mexico: An epidemic of ischemic heart disease that may be on its way?. American Heart Journal. 2010;160:230-6.

[2] Sánchez Rodríguez A, Moreno-Del Castillo C, Prado Anaya CA et al. ESTIMATED 10-YEAR CARDIOVASCULAR RISK WITH FRAMINGHAM RISK AND 2013 ACC/AHA IN GOUT AND HEALTHY MEXICAN SUBJECTS: A CASE-CONTROL STUDY WITH A PROPENSITY SCORE-MATCHED ANALYSIS J Clin Rheumatol: 2019;25:S1-S96.

[3] Bevis M, Blagojevic-Bucknall M, Mallen C, Hider S, Roddy E. Comorbidity cluster in people with gout: an observational cohort study with linked medial record review. Rheumatology (Oxford). 2018 Apr 17.

[4] Andrés M, Bernal JA, Sivera F, Quilis N, Carmona L, Vela P, Pascual E. Cardiovascular risk of patients with gout seen at rheumatology clinics following a structured assessment. Ann Rheum Dis. 2017;76:1263-8.

Disclosure of Interests: None declared.

DOI: 10.1136/annrheumdis-2021-eular.4226

\section{POS1150 ANATOMICAL LOCATIONS AND CORRELATES OF CALCIUM PYROPHOSPHATE CRYSTAL DEPOSITS OF THE SPINE - PATHOLOGIC EXAMINATION OF 77 SURGICAL CASES}

J. Dau ${ }^{1}$, G. Ho ${ }^{2}$, H. Choi ${ }^{1}$, J. Schwab ${ }^{3}$, M. Kohler ${ }^{1} .{ }^{1}$ Massachusetts General Hospital, Division of Rheumatology, Allergy, and Immunology, Boston, United States of America; ${ }^{2}$ New York University Langone Health, Division of Rheumatology, New York City, United States of America; ${ }^{3}$ Massachusetts General Hospital, Department of Orthopaedic Surgery, Boston, United States of America

Background: Spinal involvement in calcium pyrophosphate deposition disease (CPPD) is thought to be a rare occurrence and is seen infrequently as crowned dens syndrome. Furthermore, data on anatomical locations and correlates of calcium pyrophosphate (CPP) deposits in spinal CPPD are scarce.

Objectives: To describe the anatomical locations and correlates of pathologically confirmed CPPD of the spine.

Methods: Consecutive patients with spinal CPPD were identified via retrospective chart review of individuals who underwent spine surgery for intractable chronic neck or back pain at Massachusetts General Hospital between 2009 and 2014. These deposits and surrounding anatomical structures were surgically resected and confirmed to have calcium pyrophosphate deposition upon pathologic review. We reviewed musculoskeletal imaging (CT, MRI, XR) and laboratory data from these pathologically confirmed cases.

Results: From April 2009 to August 2014, we identified 77 individuals with pathologically confirmed CPPD of the spine. The mean age was 68 years; 41 (53\%) were female; mean BMI was 28.7. Calcium pyrophosphate (CPP) was grossly identified intraoperatively by the surgeon in 38 cases (50\%), typically as "chalky white deposits" (Figure 1). CPP deposits were seen most frequently in the ligamentum flavum (23\%) and intervertebral disc (23\%), followed by other less common locations (Table 1). Imaging findings in the soft tissue or intervertebral disc suggestive of CPPD were found in 5 cases $(6 \%)$, whereas findings of spinal canal narrowing, facet arthropathy, or ligamentum flavum thickening were eventually correlative with CPP deposits in pathologic specimens. Only 7 (9\%) experienced a prior episode of acute CPP arthritis (pseudogout). Chondrocalcinosis on x-ray was seen in 26 cases $(34 \%)$, most commonly in the wrist and/or knees. Osteoarthritis was present in all spinal imaging, and $65 \%$ had comorbid scoliosis. Laboratory abnormalities associated with secondary causes of CPPD (hypercalcemia, hypomagnesemia, hyperparathyroidism) were not seen with spinal CPPD.

Conclusion: Spinal CPPD may occur more frequently than previously perceived. The ligamentum flavum and intervertebral discs were common anatomical locations for spinal CPPD. Advanced imaging of the spine showed low sensitivity for detecting spinal CPPD. Only a small minority had typical peripheral joint involvement or imaging with peripheral joint chondrocalcinosis. Thus, without pathologic confirmation, the vast majority of cases would remain unidentified. These findings call for the need to seek pathologic confirmation to determine the robust epidemiology and also raise the potential role for preoperative CPPD treatment.
Table 1. Spinal Anatomic Locations of Pathologically Confirmed CPPD

\begin{tabular}{lc}
\hline Spinal Anatomic Location & No. of Sites $(\%)^{\star}$ \\
\hline ligamentum flavum & $29(23)$ \\
Intervetebral Disc & $28(23)$ \\
Other Location & $19(15)$ \\
Posterior Elements & $18(15)$ \\
Facet & $14(11)$ \\
Synovium & $8(6)$ \\
Interspinous Ligament & $3(2)$ \\
Subarticular/Lateral Recess & $2(2)$ \\
Fibrocartilaginous Tissue & $1(1)$ \\
Inner Spine & $1(1)$ \\
Other Ligament & $1(1)$ \\
\hline
\end{tabular}

*Some patients had more than one anatomic location where CPP was isolated

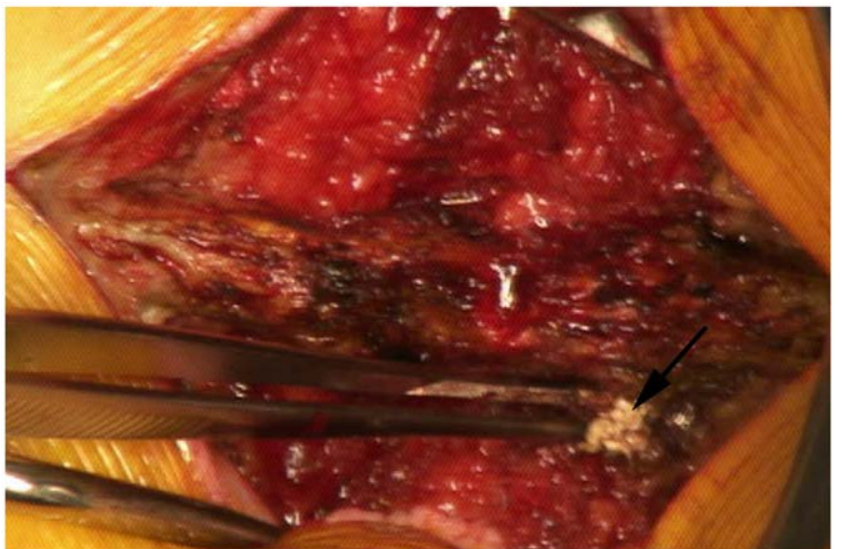

Figure 1. Gross visualization of calcium pyrophosphate deposition (black arrow)

Disclosure of Interests: Jonathan Dau: None declared, Gary Ho: None declared, Hyon Choi Consultant of: Ironwood, Selecta, Horizon, Takeda, Kowa, Vaxart, Grant/research support from: Ironwood, Horizon, Joseph Schwab: None declared, Minna Kohler Speakers bureau: Eli Lily, Consultant of: Novartis. DOI: 10.1136/annrheumdis-2021-eular.4313

\section{Infection-related rheumatic diseases}

\section{POS1151 IMMUNOGENICITY AND SAFETY OF 23-VALENT PNEUMOCOCCAL POLYSACCHARIDE VACCINE IN PATIENTS WITH SPONDYLOARTHRITIS.}

N. Muravyeva ${ }^{1}$, B. Belov ${ }^{1}$, M. Baranova ${ }^{1}$, M. Cherkasova ${ }^{2}{ }^{1}$ V.A. Nasonova Research Institute of Rheumatology, Laboratory for Studying Comorbid Infections and Monitoring the Safety of Drug Therapy, Moscow, Russian Federation; ${ }^{2}$ V.A. Nasonova Research Institute of Rheumatology, Laboratory of Immunology and Molecular Biology of Rheumatic Diseases, Moscow, Russian Federation

Background: Currently, for the treatment of patients with spondyloarthritis (SpA) basic anti-inflammatory drugs and biological drugs are widely used to effectively control the activity of the disease. At the same time, the use of these drugs is associated with an increased risk of developing infections, some of which can be prevented by vaccination.

Objectives: The aim of the study was to evaluate the immunogenicity and safety of the 23-valent pneumococcal polysaccharide vaccine (PPV-23) in patients with SpA.

Methods: The study included 42 patients with SpA: 30 men, 12 women, age 22-60 years, disease duration $14.8 \pm 10.6$ years. Ankylosing spondylitis was diagnosed in 30 patients, psoriatic spondyloarthritis - in 12 patients. Activity of diseases was assessed as high in $78 \%$ of patients (median BASDAl index was 5.3 $[4.1 ; 6.8])$. At the time of inclusion in the study, all patients received nonsteroidal anti-inflammatory drugs, 14 patients - methotrexate, 10 - sulfasalazine, 6 - glucocorticoids, 2 - leflunomide, 2 - etanercept, 2 - secukinumab. 15 patients were planned to be prescribed secukinumab, 3 - etanercept, 3 - adalimumab, 1 golimumab. 7 patients had a history of more than 2 cases of lower respiratory tract infections, 2 patients reported a monthly exacerbation of chronic sinusitis, 1 patient - the development of otitis every 2-3 months, requiring the use of antibacterial drugs. PPV-23 was administered in the amount of 1 dose $(0.5 \mathrm{ml})$ subcutaneously into the deltoid muscle against the background of anti-rheumatic therapy. 